\title{
GAYA KOMUNIKASI DAN KETERAMPILAN BERBAHASA GURU BAHASA INGGRIS DALAM MENCIPTAKAN IKLIM ORGANISASI DI SMK PENERBANGAN HASANUDDIN MAKASSAR
}

\author{
KHAIRIL ANWAR \\ Pascasarjana UIN Alauddin Makassar, Manajemen Pendidikan Islam \\ Email : arielhaeril@gmail.com
}

\begin{abstract}
:
This research is a form of research that uses quatitative, data collection techniques carried out in this study are questionnaires to students for their perceptions in seering the commination style and skills of English teacher in the learning process, this includes limits only on students within the scope of the school and direct interview process, the sample of this study was taken 60 level $X-A D M$ and $X-A P$ people from 115 level $X$ people (ADM, AP, and EA). From the results of research and discussion conducted obtained communication style (X1) and language skills (X2) have a significant effect jointly on the climate of the school organization in Hasanuddin. Flight vocation school Makassar because communication style and language skills can produce a climate of school organization that are skills and able to produce students are skilled and prosicient in English in accordance with the ideals of the school in producing alumni who are ready to use in the world of work.
\end{abstract}

Keywords: Communication Style, Language Skills.

\section{PENDAHULUAN}

G aya (Style) adalah kebiasaan khas yang dimiliki oleh seseorang atau setiap individu dalam berkomunikasi didefinisikan sebagai seperangkat sikap atau perilaku antara pribadi yang satu dengan pribadi yang lain yang digunakan pada situasi tertentu (a specialized set of interpersonal behaviors that are used in a given situation. (Smelzer 1991, 55).

Gaya komunikasi yang dibahas dalam hal ini adalah gaya komunikasi asertif, Gaya komunikasi terdapat 3 kriteria yang dikembangkan dalam kehidupan, diantaranya gaya komunikasi asertif, Nonasertif dan agresif. (Putro, Eko dkk, 2012, 156).

Asertif berasal dari kata asing yaitu to assert yang berarti menyatakan dengan tegas, menurut Izarus, pengertian perilaku asertif mengandung suatu tingkah laku yang penuh ketegasan yang timbul disebabkan adanya kebebasan emosi dan kondisi efektif yang mendukung antara lain meliputi: 1). Menyatakan hak hak peribadi. 2). Berbuat sesuatu untuk mendapatkan hak tersebut. 3). Melakukan hal tersebut sebagai suatu usaha untuk mencapai kebebasan emosi. 
Perilaku asertif adalah bentuk komunikasi secara langsung terhadap kebutuhan, keinginan dan pendapat seseorang tanpa menghukum, mengancam atau merendahkan orang lain, perilaku asertif juga melibatkan hak orang lain tanpa terlalu takut dalam proses tersebut, melibatkan ekspresi langsung dari perasaan seseorang.

Iklim organisasi adalah pola perilaku suatu individu dalam suatu kelompok yang dilakukan secara berulang yang itu di tunjukkan dalam lingkungan keseharian dari sebuah organisasi sebagai sebuah pengalaman, pemahaman, dan interpretasi individu dan iklim organisasi itu juga merupakan sebuah lingkungan yang menyenangkan atau tidak menyenangkan bagi orang orang dalam organisasi itu sendiri dan hal ini kemudian berdampak pada kepuasan kerja peserta organisasi (Robbins, Stephen P. 2008. 134).

Dalam kehidupan bermasyarakat antara satu dengan yang lainnya saling berhubungan dengan saling berinteraksi satu sama lain maka dalam hal ini terjadi proses komunikasi yang dalam istilah ini kita kenal dengan Encoder dan Decoder dalam komunikasi si pengirim pesan mungkin memberikan gambaran pesan yang di sampaikan dengan bahasa isyarat atau yang di sebut Decoding lalu kemudian si penerima pesan merespon dengan bahasa lisan wujud dari pesan yang di sampaikan oleh si pengirim pesan yang kemudian di sebut dengan Encoding.

Seseorang dikatakan memiliki keterampilan berbicara apabila yang bersangkutan dengan terampil memilih bunyi-bunyi bahasa (berupa kata, kalimat, serta tekanan dan nada) secara tepat serta memformulasikannya secara tepat pula guna menyampaikan pikiran, perasaan, gagasan, fakta, perbuatan dalam suatu konteks komunikasi tertentu. Kemudian, seseorang dikatakan terampil mendengarkan (menyimak) apabila yang berhubungan dan memiliki kemampuan menafsirkan makna dari bunyi-bunyi bahasa (berupa kata, kalimat, tekanan, dan nada) yang disampaikan pembicara dalam suatu konteks komunikasi tertentu.

Berdasarkan dari latar belakang dapat dirumuskan masalah sebagai berikut:

1. Apakah Gaya Komunikasi guru bahasa Inggris berpengarus signifikan terhadap Iklim Organisasi?

2. Apakah keterampilan berbahasa Guru bahasa Inggris berpengaruh terhadap Iklim Organisasi ?

3. Apakah Gaya Komunikasi dan keterampilan berbahasa guru bahasa Inggris berpengaruh terhadap Iklim organisasi di SMK Penerbangan Hasanuddin Makassar?

\section{Teori Gaya Komunikasi}

Teori gaya komunikasi yang digunakan dalam penelitian ini adalah teori yang diungkapkan oleh Smelzer et al (1991, 7): “Manager requires an interated system in this leadership process concisting of how it is in process of strategy communication plan, and determining leader communication mode". Setiap orang 
mempunyai gaya dalam berkomunikasi berbeda beda berdasarkan gaya, tatakrama dalam pola aliran informasi dalam sebuah organisasi.

\section{Gaya Komunikasi Asertif Guru Bahasa Inggris}

Gaya komunikasi guru dengan menggunakan gaya komunikasi asertif merupakan sebuah penerapan dalam diri seorang pendidik tentang bagaimana seharusnya seorang guru mengungkapkan ekpresinya kepada siswa dan iklim organisasi sekolah sehingga terjadi sebuah interaksi yang menyenangkan yang secara tidak langsung hal itu akan menumbuhkan semangat atau motivasi siswa terhadap mata pelajaran yang dalam hal ini pelajaran Bahasa Inggris.

Asertif juga merupakan bentuk ketegasan dan keberanian menyampaikan pendapat dan itu meliputi tiga komponen dasar yaitu 1) kemampuan mengungkapkan perasaan, 2) kemampuan mengungkapkan keyakinan dan pemikiran secara terbuka, seperti mampu menyatakan pendapat, menyatakan ketidak setujuan dan sikap tegas, 3) kemampuan untuk mempertahankan hak hak pribadi tidak membiarkan orang lain mengganggu dan mempermainkan hak hak kita. Berdasarkan penjelasan diatas memberikan pemahaman kepada kita bahwa dengan Gaya komunikasi yang ditampilkan oleh Guru Bahasa Inggris dengan pola pengajaran yang efektif akan memberikan efek positif terhadap kompetensi siswa dalam menangkap pelajaran dengan motivasi dan semangat yang tinggi. (Farida, 2016, 21).

Oleh karena itu dalam menampilkan pelajaran Bahasa Inggris berdasarkan gaya komunikasi asertif penulis mengemukakan tiga poin penting yang perlu diperhatikan oleh Guru bahasa Inggris dalam berkomunikasi dengan peserta didik dalam menerapkan pembelajaran bahasa Inggris yang efektif, seperti berikut ini:

\section{Guide Conversation.}

Keterampilan berbicara (Speaking Skill) dalam bahasa Inggris adalah suatu keterampilan seseorang untuk menyampaikan keinginan dan pemikirannya kepada siapa saja melalui lisan, akan tetapi keterampilan berbicara sulit berkembang kalau tidak dilatih secara terus menerus dan bisa dilakukan dengan teman temannya di dalam kelas, guru-guru bahasa Inggris, atau guru-guru lainnya yang bisa berbahasa Inggris. inilah yang menjadi ukuran bahwa kemampuan berkomunikasi verbal bagi guru bahasa Inggris mempunyai tujuan untuk memperlancar keterampilan berbicara, memperkaya penggunaan kosa kata, memperbaiki tatanan berbahasa, menyempurnakan ucapan-ucapan kosa kata, kalimat-kalimat bahasa Inggris, dan melatih pendengaran sehingga mudah menangkap pesan dari lawan bicara.

Dari arti kata Guided di atas, yang erat kaitannya dengan proses pembelajaran asertif yang mengacu keterampilan berbicara Bahasa Inggris yaitu "membimbing dan memandu" siswa dalam belajar sehingga kemampuan mereka terasah lebih berkembang Antara membimbing dan memandu mempunyai persamaan arti dan tujuan karena kedua kata tersebut sama-sama menuntun 
siswa ke arah yang cemerlang (bisa berbicara) bahasa Inggris. (Djamarah, 2007,138).

\section{Structural Conversation.}

Penggunaan Bahasa Inggris baik dalam percakapan sehari-hari maupun penggunaan bahasa tulisan harus tepat dan benar dalam segi apapun karena berhubungan dengan waktu: lampau, sekarang dan akan datang. Selain itu penggunaan structure bahasa Inggris terkait dengan penggunaan bentuk noun, pronoun, articles, dan bermacam bentuk kata: adjective, verbs, dan adverbs.

Dengan demikian, materi conversation atau percakapan bertujuan untuk membangkitkan potensi belajar dengan gaya asertif siswa dan seluruh lingkungan iklim organisasi kelas, mampu menggunakan fungsi-fungsi komunikasi/percakapan Bahasa Inggris dengan baik dan benar dalam percakapan sehari-hari baik secara formal maupun non-formal.

\section{Functional Conversation}

Percakapan atau Coversation ditujukan untuk membentuk kemampuan siswa dalam memfungsikan bahasa menurut tempat dan keberadaannya.ini dilakukan oleh Guru Dalam proses percakapan sehari-hari (daily conversation) dan sering dihadapkan kepada sesuatu yang objektif dalam berkomunikasi bahasa Inggris.

Percakapan antara guru dan siswa atau Conversation kemudian dijabarkan dalam beberapa penerapan, Ini merupakan panduan percakapan atau perbincangan yang dilakukan dalam bahasa Inggris sederhana dalam rangka memperlancar komunikasi dan meningkatkan hasil belajar dalam keterampilan berbicara Bahasa Inggris dalam iklim organisasi kelas. Functional Conversation memberikan inspirasi kepada siswa dan lingkungan iklim organisasi sekolah untuk menciptakan suasana komunikatif dalam memberikan ide, serta memaparkan pemikiran dan tanggapan sekaligus memberikan kritikan dalam membetulkan perbincangan karena setiap kalimat yang diucapkan dalam percakapan mempunyai fungsi dan tujuan masing masing bergantung pada suasana, lingkungan dan individu dalam bercakap. Dari tipe dan jenis percakapan diatas dapat digambarkan bahwa proses keterampilan berbicara bisa dikembangkan dengan baik dan cepat karena arahan dan tuntunan yang muncul dari konsep Guided Conversation, Structural Conversation, Functional Conversation.

Gaya Komunikasi yang di hasilkan dari seorang Guru bahasa Inggris dalam menampilkan Gaya Komunikasi yang khas dapat membangkitkan motivasi belajar, prestasi belajar, serta minat belajar siswa terhadap pelajaranBahasa Inggris bergantung dari metode yang digunakan sebagaimana yang dijelaskan, dengan menggunakan gaya komunikasi asertif yang lebih mengedepankan rasa kebersamaan dan menghargai hak dan pendapat siswa dalam belajar dan memahami pelajaran bahasa Inggris maka Guide conversation, Structural Conversation, Functional Conversation akan dapat memotivasi siswa untuk lebih 
tampil percaya diri dalam mengungkapkan apa yang dipahami dan dipelajari pada pembelajaran bahasa Inggris.

\section{Keterampilan Berbahasa}

Dalam kehidupan sosial kita dihadapkan pada kegiatan komunikasi dua arah yang saling berkomunikasi maka sederhananya terjadi sebuah proses yang di sebut "Pengirim dan "Penerima atau Encoder dan Decoder. Encoder atau pengirim pesan mengirim pesan dan decoder menerjemahkan pesan itu dan diolah sehingga menciptakan suasana komunikasi yang sejalan dan seirama, pengirim pesan mengirim sinyal pesan menjadi penanda dan penerima menerjemahkan pesan itu.

Melihat proses komunikasi seperti digambarkan diatas, maka keterampilan berbahasa dapat dikelompokkan ke dalam dua kategori, yakni aspek reseptifdan aspek produktif. Aspek reseptif bersifat penerimaan atau penyerapan, seperti yang tampak pada kegiatan menyimak dan membaca, sementaraaspek produktif bersifat pengeluaran atau pemroduksian bahasa, baik lisan maupun tertulis sebagaimana yang tampak dalam kegiatan berbicara dan menulis. Aktivitas tersebut biasa kita kenal dengan istilah aktivitas berbicara. Dipihak lain, si penerima melakukan aktivitas decoding berupa pengubahan bentuk-bentuk bahasa yang berupa bunyi-bunyi lisan menjadi pesan sesuai dengan maksud si pengirimnya. Aktivitas tersebut biasa kita sebut dengan istilah mendengarkan (menyimak).

Keterampilan berbahasa ada empat aspek, yaitu keterampilan menyimak, berbicara, membaca, dan menulis. Menyimak dan membaca merupakan aspek reseptif, sementara berbicara dan menulis merupakan aspek produktif. Dalam aktivitas berbicara, si pengirim pesan mengirimkan pesan dengan menggunakan bahasa lisan. Sementara, dalam menyimak si penerima pesan berupaya memberi makna terhadap bahasa lisan yang disampaikan si penyampainya. Dalam kegiatan menulis, si pengirim pesan mengirimkan pesan dengan menggunakan bahasa tulis.

\section{Iklim Organisasi}

Iklim Organisasi adalah pola atau perilaku yang sudah diadopsi masyarakat sebagai pemecahan masalah anggota dalam organisasi tersebut Iklim organisasi termasuk didalamnya kepercayaan, norma, nilai-nilai yang mendasar dan mengandung perintah. Iklim organisasi juga diartikan sebagai persepsi tentang kebijakan praktek-praktek dan prosedur-prosedur organisasional yang dirasakan dan diterima oleh individu-individu dalam organisasi. Iklim kerja organisasi secara relatif merupakan kualitas lingkungan internal dari organisasi yang dipertahankan dan membedakan organisasi tersebut dengan organisasi lain. Dimensi iklim organisasi di kemukakan dengan beberapa faktor yaitu: a)Tanggung jawab, b)Standar atau harapan tentang kualitas pekerjaan, c)Ganjaran atau reward, 
d)Rasa persaudaraan, e)Semangat tim dan f)Komitmen bersama dalam mencapai visi dan misi Organisasi.(Robbins, Stephen P, 2008, 134)

Dengan demikian Iklim Organisasi merupakan sebuah suasana kelembagaan yang terbentuk dengan adanya tanggung jawab terhadap apa yang di jadikan acuan atau apa yang diusung untuk menjadi cita cita bersama dalam sebuah organisasi sehingga dampak ketika terjadinya konflik baik eksternal maupun internal dalam organisasi akan di selesaikan dengan baik karena tumbuhnya sebuah tanggung jawab.

Iklim organisasi sekolah yang positif dapat terjadi dengan terjalinnya hubungan yang baik dan harmonis antara yayasan atau penyelenggara pendidikan guru dengan seluruh siswa. Faktor-faktor penentu iklim organisasi sekolah terdiri dari 1) Ekologi yaitu lingkungan fisik seperti ruangan, bangku, kursi, alat elektronik, dan lain-lain, 2) Hubungan sosial, 3) Sistem sosial yaitu perorganisasian,pengambilan keputusan dan pola komunikasi, 4) Budaya yakni nilai-nilai kepercayaan, norma dan cara berpikir orang-orang dalam organisasi kelas, dan faktor-faktor yang mempengaruhi Iklim Organisasi adalah : 1) Struktur tugas, 2) Imbalan dan hukuman yang diberikan, 3) Sentralisasi keputusan, 4) Tekanan pada prestasi, 5) Tekanan pada latihandan pengembangan, 6) Keamanan dan resiko pelaksanaan tugas, 7) Keterbukaan dan Ketertutupan individu, 8) Pengakuan dan umpan balik, 9) Kompetensi dan fleksibilitas dalamhubungan pencapaian tujuan organisasi secara fleksibel dan kreatif". (Milner dan Khozabahwa 2009: 21)

Iklim Organisasi sekolah merupakan kualitas dari lingkungan yang terus menerus dialami oleh guru-guru yang mempengaruhi tingkah laku dan berdasar pada persepsi kolektif tingkah laku mereka. Iklim organisasi sekolah adalah produk akhir dari interaksi antar kelompok peserta didik di ruang kelas, dan lingkungan sekolah,guru dan peserta didik yang bekerja untukmencapai keseimbangan antara dimensi organisasi (sekolah) dengan dimensi individu yang merupakan karakteristik yang menggambarkan ciri-ciri psikologis dari siswa tertentu.

Iklim ruang sekolah yang kondusif baik fisik maupun non fisik merupakan landasan bagi penyelenggaraan pembelajaran yang efektif dan produktif. Oleh karena itu, ruang kelas perlu menciptakan iklim yang kondusif untuk menumbuh kembangkan semangat dan merangsang nafsu belajar peserta didik dalam proses pembelajaran sehingga dengan iklim yang kondusif diharapkan tercipta suasana yang aman, nyaman, dan tertib, sehingga pembelajaran dapat berlangsung dengan tenang dan menyenangkan. Iklim organisasi yang kondusif antara lain meliputi:

a) Lingkungan yang aman, nyaman dan tertib

b) Ditunjang oleh optimisme dan harapan warga sekolah atau warga kelas

c) Kesehatan sekolah atau kelas

d) Kegiatan-kegiatan yang berpusat pada perkembangan peserta didik. 


\section{METODE PENELITIAN}

Penelitian ini merupakan bentuk penelitian yang menggunakan format kuantitatif ialah penelitian yang bertujuan untuk mengukur sebuah instrumen atau objek dalam hitungan statistik yang menggambarkan kondisi, sebagai situasi atau fenomena realitas sosial yang ada ada didalam sebuah Iklim organisasi bernama Sekolah yang menjadi objek penelitian, dan berupaya menarik realitas itu kepermukaan sebagai suatu ciri, karakter, sifat, model, tanda, atau gambaran tentang kondisi, situasi, ataupun fenomena tertentu( Burhan Bungin, 2005, 44 ).

Penelitian ini menggunakan 2 variabel independen $(X)$ dan 1 variabel dependen (Y).

\begin{tabular}{|c|c|c|}
\hline Variabel & Sub Variabel & Indikator \\
\hline Gaya Komunikasi & $\begin{array}{l}\text { Gaya Komunikasi Asertif } \\
\text { Guru Bahasa Inggris Di } \\
\text { SMK Penerbangan } \\
\text { Hasanuddin Makassar }\end{array}$ & $\begin{array}{l}\text { 1. Guide Convertation } \\
\text { 2. Structural Convertation } \\
\text { 3. Functional Convertation }\end{array}$ \\
\hline Keterampilan Berbahasa & $\begin{array}{l}\text { Pengaruh keterampilan } \\
\text { berbahasa Inggris Dalam } \\
\text { Iklim organisasi di } \\
\text { Lingkungan SMK } \\
\text { Penerbangan Hasanuddin } \\
\text { Makassar }\end{array}$ & $\begin{array}{l}\text { 1. Keterampilan } \\
\text { menyimak } \\
\text { 2. Keterampilan berbicara } \\
\text { 3. Keterampilan } \\
\text { membaca } \\
\text { 4. Keterampilan menulis }\end{array}$ \\
\hline Iklim Organisasi & $\begin{array}{l}\text { Iklim Organisasi kelas di } \\
\text { SMK Penerbangan } \\
\text { Hasanuddin Makassar }\end{array}$ & $\begin{array}{l}\text { 1. Lingkungan yang } \\
\text { aman, nyaman dan } \\
\text { tertib } \\
\text { 2. Ditunjang oleh } \\
\text { optimisme dan } \\
\text { harapan organisasi } \\
\text { sekolah } \\
\text { 3. Kesehatan sekolah } \\
\text { 4. Kegiatan-kegiatan yang } \\
\text { berpusat pada } \\
\text { perkembangan } \\
\text { peserta didik }\end{array}$ \\
\hline
\end{tabular}

Teknik pengumpulan data yang dilakukan dalam penelitian ini adalah kuesioner terhadap siswa atas persepsi mereka dalam melihat gaya komunikasi dan keterampilan guru bahasa inggris dalam proses pembelajaran, ini meliputi batasan hanya pada siswa dalam lingkup sekolah dan proses wawancara langsung dilakukan dalam penelitian ini kepada guru yang diteliti secara nonformal, kuesioner yang dilakukan dan menggunakan rumus statistik SPSS 24. Adapun sampel penelitian ini diambil 60 Orang yang merupakan taruna (i) Tingkat X-ADM dan X-AP dari 115 orang tingkat X (ADM, AP dan EA) tahun ajaran 2018/2019 melalui simple random sampling (secara rambang sederhana). Penarikan rambang 
kelas dilakukan agar tidak terlalu banyak mengganggu proses pembelajaran di sekolah.

\section{HASIL PENELITIAN DAN PEMBAHASAN}

Analisis ini menggunakan data- data responden dan hasil kuisioner yang telah peneliti sebarkan. nilai signifikansi dari test for linearity lebih kecil dari 0,05, ini mengindikasikan bahwa model regresi adalah linier. Berdasarkan nilai signifikansi dari tabel diatas diperoleh nilai Deviation from Linearity adalah 0,114 lebih besar dari 0,05. Maka dapat disimpulkan ada hubungan linear signifikan antara Variabel $X_{1}$ dengan $Y_{1}$.

Berdasarkan nilai signifikansi dari table diatas diperoleh nilai Deviation from Linearity adalah 0,418 lebih besar dari 0,05. Maka dapat disimpulkan ada hubungan linear signifikan antara Variabel $X_{2}$ dengan $Y_{1}$. Data perhitungan diatas menunjukan bahwa nilai signifikansi untuk gaya komunikasi

Berdasarkan hasil analisis dengan menggunakan SPSS 24 diperoleh data didapatkan nilai signifikansi sebesar $0.004(p<0,05)$ maka dapat disimpulkan bahwa hipotesis diterima, artinya variabel Gaya komunikasi dan Keterampilan Berbahasa berpengaruh signifikan secara bersama sama terhadap iklim organisasi.

\section{Pengaruh gaya komunikasi guru Bahasa Inggris terhadap Iklim organisasi Sekolah di SMK Penerbangan Hasanudddin Makassar.}

Hasil yang ditemukan berdasarkan data hasil perhitungan hipotesis dengan menggunakan uji regresi linear berganda membuktikan bahwa gaya komunikasi guru bahasa inggris berpengaruh signifikan terhadap iklim organisasi sekolah di SMK penerbangan Hasanuddin Makassar, yang artinya hipotesis pertama diterima. Seperti yang telah diteliti oleh Nurhayati dengan judul penelitian Strategi Peningkatan Perilaku Asertif Anak usia dini melalui Pembelajaran Bermain Peran penelitiannya menemukan bahwa ada hubungan yang erat antara kemampuan seorang guru dalam menampilkan gaya komunikasi yang menarik bagi peserta didik dalam menumbuhkan sikap percaya diri saat tampil baik didalam kelas maupun diluar lingkungan sekolah serta mampu lebih aktif dalam proses pembelajaran.

Pada kondisi dilapangan dalam penelitian ini menjelaskan bahwa dengan adanya Guide converstation yakni keterampilan berbicara untuk menyampaikan didalam kelas tentunya akan menjadi tolok ukur dalam melakukan komunikasi antara guru dan siswa di lingkungan sekolah.

Structural converstation merupakan rangkaian dari peroses pembelajaran bahasa inggris yang struktural atau menggunakan tata bahasa/grammar, pada kondisi dilapangan penelitian ini menjelaskan bahwa adanya proses pembelajaran yang efektif dalam pembelajaran bahasa inggris karena guru memberikan pembelajaran kepada siswa dengan memberikan penjelasan makna kata kata 
tertentu secara gramatikal atau struktur bahasa sehingga siswa mampu mengkomunkasikan bahasa inggris dengan baik dan efektif.

Pengaruh keterampilan berbahasa guru bahasa inggris Terhadap iklim organisasi sekolah di SMK Penerbangan Hasanuddin Makassar.

Keterampilan berbahasa yang meliputi kemampuan menyimak/mendengar, membaca dan menulis hubungannya dengan iklim organisasi sekolah maka ia akan menjadi instrument pendukung dalam proses dan pelaksanaan pembelajaran dan pelaksaan kurikulum sekolah termasuk literatur dan ilmu pengetahuan.

Hasil dari penelitian tersebut menunjukkan bahwa adanya pengaruh antara kemampuan atau skill berbahasa yang terdiri dari sikap menyimak atau mendengar, membaca dan menulis mempunyai pengaruh pada iklim organisasi sekolah sebagaimana hasil penelitian yang dipaparkan dalam bentuk kuesioner dan wawancara.

\section{Pengaruh gaya komunikasi dan keterampilan berbahasa guru bahasa Inggris dalam menciptakan iklim organisasi di SMK Penerbangan Hasanuddin Makassar.}

Gaya komunikasi dan keterampilan berbahasa terhadap iklim organisasi sekolah di SMK Penerbangan Hasanuddin Makassar mempunyai pengaruh yang signifikan dengan hasil penelitian di lapangan dengan pemaparan yang dilakukan dalam bentuk angket atau kuesioner, yang menghasilkan bahwa adanya proses pembelajaran yang efektif pada saat seorang guru bahasa Inggris melakukan proses mengajar.

\section{PENUTUP/SIMPULAN}

Dari hasil penelitian dan pembahasan yang dilakukan oleh peneliti terkait dengan pengaruh gaya komunikasi dan keterampilan berbahasa guru bahasa Inggris dalam menciptakan iklim organisasi di SMK Penerbangan Hasanuddin Makassar bahwa gaya komunikasi guru $\left(X_{1}\right)$ berpengaruh signifikan terhadap iklim organisasi sekolah SMK Penerbangan Hasanuddin Makassar setelah dilakukan uji lienerasi di lapangan dan dengan melakukan uji angket kepada warga sekolah ditemukan hasil bahwa gaya komunikasi guru hanya mempunyai dampak yang signifikan pada saat terjadi sebuah interaksi atau proses pembelajaran, sementara iklim organisasi lebih luas cakupannya, dan keterampilan berbahasa Guru Bahasa Inggris $\left(X_{2}\right)$ berpengaruh signifikan terhadap Iklim Organisasi Sekolah di SMK Penerbangan Hasanuddin Makassar karena pada saat proses pembelajaran dan interaksi dengan siswa, guru melakukan proses transfer ilmu pengetahuan sehingga mengharuskan seorang guru tampil dengan sikap profesionalisme yang tinggi dan dapat menghasilkan murid murid yang berkualitas dengan tampilnya seorang guru yang berkualitas dan professional dalam mengajar.

Gaya Komunikasi (X1) dan keterampilan berbahasa (X2) berpengaruh signifikan secara bersama sama terhadap iklim organisasi Sekolah di SMK 
Penerbangan Hasanuddin Makassar karena gaya komunikasi serta keterampilan bahasa dapat menghasilkan iklim organisasi sekolah yang terampil dan mampu menghasilkan siswa siswa terampil dan cakap dalam berbahasa inggris yang sesuai dengan cita cita sekolah dalam mencetak alumni alumni yang siap pakai didunia kerja.

\section{DAFTAR PUSTAKA}

Arikunto, Suharismi. Manajemen Penelitian. Cet. XI; Jakarta: Rineka Cipta, 2010.

Bunging, Burhan. 2007. Penelitian Kualitatif: Komunikasi, Ekonomi, Kebijakan Publick, dan IImu Sosial Jakarta: Kencana.

Putro, Eko dkk. Pengaruh Kinerja Guru terhadap Motivasi Belajar Siswa. Cakrawala Pendidikan, 2012

P. Robbins, Stephen. Perilaku Organisasi; diterjemahkan oleh Tim Indeks, Jakarta: Penerbit Indeks Kelompok Gramedia, 2003.

Yusuf, Muri. Metode Penelitian: Kuantitatif, Kualitatif \& Penelitian Gabungan.Cet. I; Jakarta: Kencana, 2014. 